\title{
Effect of Poultry Manure on Pepper Veinal Mottle Virus (PVMV), Yield and Agronomic Parameters of Pepper (Capsicum annuum) in Nigeria
}

\author{
Fajinmi A. A. ${ }^{1^{*}}$ and Odebode C.A. ${ }^{2}$ \\ ${ }^{1}$ Crop Protection Department, Colplant, University of Agriculture, Abeokuta P.M.B 2240, Alabata Abeokuta, Ogun \\ State, Nigeria \\ ${ }^{2}$ Department of Botany and Microbiolgy, University of Ibadan, Ibadan, Oyo State, Nigeria
}

\begin{abstract}
Four fertilizer treatments were applied to two PVMV susceptible pepper (Capsicun annuum) varieties (NHV1-D96 and NHV1-E96) and one PVMV tolerant variety (NHV1-G96) to determine their effects in reducing the incidence and severity of pepper veinal mottle virus disease and on yield and agronomic parameters. The treatments were: (1) no manure application, (2) poultry litter organic manure at the rate of 10 tons/ha, (3) poultry litter organic manure at the rate of 20 tons/ha, and (4) NPK (20:10:10) at the rate of 0.26 tons/ha inorganic fertilizer. Broadcasting method was used for all the fertilizer applications. The experiment was carried out both in the field using a randomized complete block design and in $5 \mathrm{~kg}$ sterilized soil-potted experiment in the greenhouse in complete randomized design. The treatments showed a significant effect $(\mathrm{P}<0.01)$ on PVMV disease incidence and severity, plant height, leaf number, internodes distance, number of fruit per plant, and fruit yield both in the field and greenhouse plants. The interactions between the treatments were also significant $(\mathrm{P}<0.05)$ for PVMV disease incidence and severity, plant height, leaf number, internodes distance, number of fruit per plant and fruit yield. Mean PVMV disease incidence and severity, plant height, leaf number, internodes distance, number of fruit per plant and fruit yield, varied significantly $(\mathrm{P}<0.05)$ in all the treatments applied. The application of 10 tons/ha and 20 tons/ha poultry manure showed a significant $(\mathrm{P}<0.01)$ effect in reducing the incidence and severity of PVMV disease on the three pepper varieties. The poultry manure treatments were also observed to have positively and significantly contributed $(\mathrm{P}<0.05)$ to the plant height, leaf number and fruit yield of PVMV infected pepper plants in all the three pepper varieties used both in the field and in the greenhouse. The yield of pepper decreased with increasing PVMV disease incidence and severity in all the treatments.
\end{abstract}

Keywords: Capiscum annuum; Pepper Veinal Mottle Virus; Poultry Organic Manure

\section{Introduction}

Pepper veinal mottle virus (PVMV) (genus Potyvirus, family Potyviridae) disease has been a major constraint to pepper production, contributing to low yield and reduced fruit quality and leading to great economic loss (Cook, 1991). In Nigeria, 100\% losses of marketable fruit due to infection with PVMV have been reported causing whole field to be abandoned prior to harvest and in some areas making cultivation of pepper to be uneconomical (Alegbejo and Uvah, 1987). Peppers infected by PVMV exhibit varied symptom expression depending on the severity, age of plant, time of infection and pepper variety. These symptoms may appear on the leaves, stem, flowers and fruits (Zethner, 1991). The symptoms exhibited include mild mottle, mosaic, vein banding, ring spots, various types of necrosis, leaf discoloration, deformation, blistering and severe stunting of the whole plant (Green and Kim, 1991).

The issue of satisfactory control of this PVMV has been a major problem that has led to reduce cultivation of this crop in most part of the world and especially in Nigeria. Many control methods have been practiced, which include, host resistance, biological control, plant quarantine, chemical control and field sanitation (Hussey, 1990; Kirkby, 1990; Gahukar, 1991). But an adequate control of the PVMV disease under field conditions has not been achieved (Zethner, 1991).

The economic control of many insect pests that are the major vectors of PVMV has led to the excessive use of chemicals, which has many hazardous effects on the environments. Insecticide application and removal of infected plants are usually inadequate in reducing virus spread (Beth, 2005). Most of these insect pests are fitted to thrive in agro ecosystems and to adapt to changing crop production conditions.

In view of this, Pottorff (2004) suggested the use of organic manure as a cultural control method in controlling viral diseases of most horticultural crops. Organic manure encourages beneficial microorganism to live in a symbiotic relationship with plants, improving their fertility and disease resistance. It initiates the cycling of organic material, within the soil, by the microorganisms, which cause decomposition. The organic soil relies on this cycling to produce organic solutions, which are aimed at being preventative, by improving the natural balance within the garden to build a healthy soil (Robert et al., 2001). This organic manure serves as a source of slow release of required nutrient and trace elements, which are critical to plant health, and this is a good way to add these essential nutrients (Beth, 
2005). This helps to avoid high nitrogen fertilizers that may result from the use of inorganic fertilizers, such as NPK, as soft new growth makes the plants to be very vulnerable to viral diseases (Pottorff, 2004). It is for this prudent reason that we must understand nature's mechanisms of regulating population and maximizes their applications for successful viral disease control.

Therefore, this study was targeted at determining the efficacy and effect of cured poultry litter manure as a source of organic nutrient in reducing the incidence and severity of the PVMV disease and its effect on the yield and other agronomic parameters of cultivated pepper.

\section{Materials and Methods}

The experiment was carried out in 2004 and 2005 in the green house and experimental field of the University of Agriculture Abeokuta, Alabata, located on $7^{\circ} 10^{\prime} \mathrm{N}$ and $3^{\circ} 2^{\prime} \mathrm{E}$ in Odeda Local Government area of Ogun State Nigeria. The area lies in the southwestern part of Nigeria having a prevailing tropical climate with a mean annual rainfall of about $1037 \mathrm{~mm}$ and mean ambient temperature ranges from $28{ }^{\circ} \mathrm{C}$ in December to $30{ }^{\circ} \mathrm{C}$ in February with a yearly average of $34{ }^{\circ} \mathrm{C}$.

\subsection{Treatments}

Three pepper varieties, NHV1-D96 and NHV1-E96, PVMV susceptible varieties and NHV1-G96, a highly PVMV tolerant variety (Fajinmi et. al., 1998), obtained from National Horticultural Research Institute (NIHORT) Idi-Ishin, Ibadan were used for this experiment. The highly tolerant variety used served as control check. Poultry litter was used as source of organic manure, while the inorganic fertilizer treatment used was NPK fertilizer $\left(\mathrm{N}-20 \%, \mathrm{P}_{2} \mathrm{O}_{5}-10 \%, \mathrm{~K}_{2} \mathrm{O}-\right.$ $10 \%)$. The poultry litter used as source of organic manure for the treatment was collected from droppings of poultry laying chickens of the University of Agriculture Abeokuta and left in the open for four weeks to compost (so as to reduce the acidity content) before application. The nutrient composition of the poultry litter used was analyzed and determined. Healthy pepper seedlings varieties were raised in the greenhouse and transplanted at 5 weeks old in May during the rainy season.

\subsection{Experimental Design for Field Experiment}

The experimental design used in the field was a randomized complete block design. The plot size was 2 $\mathrm{m} \times 2 \mathrm{~m}$ with an interplot spacing of $1.0 \mathrm{~m}$ and interblock spacing of $2.0 \mathrm{~m}$. The plots were replicated three times for each level of fertilizer treatment application in each variety of pepper used. Sixteen healthy and five week old pepper seedlings of each variety were transplanted at a spacing of $50 \mathrm{~cm} \mathrm{x} 60 \mathrm{~cm}$ per plot replicated three times.

The three pepper varieties (NHV1-D96, NHV1-E96 and NHV1-G96) were used as main treatments while fertilizer application at different ratio were used as subplot treatments. Using the recommendation of Olasantan
(1994), four treatments were used in the sub-plot: (1) no manure application, (2) 10 tons/ha poultry manure (3) 20 tons/ha poultry manure and (4) $260 \mathrm{~kg} / \mathrm{ha}$ of NPK (20:10:10) fertilizer. Broadcasting method was used for all the fertilizer application to allow for good distribution and uniform spreading of the manure across the plot.

The organic fertilizers were applied two weeks before pepper seedling transplant while the inorganic fertilizer was applied three weeks after pepper seedling transplant. To increase density of PVMP inoculum, two rows of four weeks old pepper seedlings of bell fruit shaped "Tattasai" varieties each mechanically inoculated with PVMV and which has been confirmed through PAS-ELISA were planted at a spacing of $50 \mathrm{~cm}$ by $60 \mathrm{~cm}$ within the inter-block spacing. There was no insecticide application. Weeding of the plot was done at three weeks interval after transplanting.

Before the fertilizer application, a representative soil sample from each plot was collected and the nutrient composition analyzed and determined in the soil laboratory of University of Agriculture Abeokuta after eight weeks of pepper transplant. The representative soil sample from each plot was recollected and the nutrient composition analyzed and determined in the soil laboratory to determine the increase in nutrient composition of the plots. The nutrients analyzed were: nitrogen $(\mathrm{N})$, phosphate $\left(\mathrm{P}_{2} \mathrm{O}_{5}\right)$, potash $\left(\mathrm{K}_{2} \mathrm{O}\right)$, calcium, magnesium, sulphur, sodium, iron, zinc, \% organic carbon and \% organic matter, soil particle analysis, excess acidity and the $\mathrm{pH}$.

Viral disease incidence and severity were monitored on the pepper plants (four center plants from a population of sixteen plants per plot) in each treatment plot leaving the guard rows by using a modified formula-grading scheme (Steel and Torrie, 1980; Merritt, et al., 1999), for disease incidence and severity as follow:

1. No disease symptoms

2. Leaf mottling

3. Chlorosis / leaf mottling

4. Severe mottling / leaf bunching

5. Leaf defoliation.

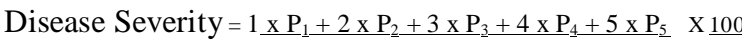
$\mathrm{N}(\mathrm{G}-1)$

Percentage Disease Incidence $=\frac{\mathrm{N}-\mathrm{n}}{\mathrm{N}} \times \frac{100}{1}$

Where: $\mathrm{P}_{1}$ to $\mathrm{P}_{5}=$ Total number of observations in each disease symptoms grading.

$\mathrm{G}=$ Number of grading $=5$

$\mathrm{N}=$ Total number of observations

$\mathrm{n}=$ Total number of plants with no disease symptoms

Pepper leaf samples showing virus disease symptoms were sampled for serological analysis using PAS-ELISA as described by Green (1991) to confirm the presence of PVMV. Representative pepper leaf samples infected with PVMV were collected and sent to Dr. Stephan Winter, Head, DSMZ Plant Virus Division Braunschweig Germany for the virus electron 
microscopy and characterization. The yield of the pepper fruit was recorded in each plot for a period of 12 weeks. Other agronomic data such as, plant height, leaf number, internodes distance, and fruit number were recorded.

The results were analyzed statistically using analysis of variance procedure. The means were separated using least significant difference (LSD) tests.

\subsection{Pot Experiment}

In the greenhouse thirty-six pots were filled with $5 \mathrm{~kg}$ of sterilized soil in the greenhouse. The soil was collected from the field used for the field trial and representative soil sample was taken for nutrient composition analysis. The nutrients analyzed for were: nitrogen $(\mathrm{N})$, phosphate $\left(\mathrm{P}_{2} \mathrm{O}_{5}\right)$, potash $\left(\mathrm{K}_{2} \mathrm{O}\right)$, calcium, magnesium, sulphur, sodium, iron, zinc, $\%$ organic carbon and \% organic matter, soil particle analysis, excess acidity and the $\mathrm{pH}$. The organic fertilizers were applied two weeks before pepper seedling transplant while the inorganic fertilizer was applied three weeks after pepper seedling transplant. There was no insecticide application. Weeding of the pot was done weekly after transplanting.

Four treatments were also used in the pot experiment; (1) no manure application, (2) 30.692 gram of poultry litter organic manure per pot replicate (i.e. at the rate of 10 tons/ha), (3) 61.384 gram of poultry litter organic manure per pot replicate (i.e. at the rate of 20 tons/ha), and 0.58 gram of N.P.K (20:10:10) inorganic fertilizer treatment per pot replicate (i.e. at the rate of $260 \mathrm{~kg} / \mathrm{ha}$ inorganic fertilizer). The three pepper varieties (NHV1D96, NHV1-E96 and NHV1-G96) were also used for this pot experiment. One healthy five-week-old pepper seedling of each variety was transplanted per pot and replicated five times for each treatment. After the fifth day of the four-week-old pepper seedling transplant, all the transplanted seedlings for each variety were inoculated with PVMV sap extract that has been maintained on a bell shaped pepper variety and confirmed to be PVMV serologically positive through PAS-ELISA as described by Green (1991). The potted plants were arranged in complete randomized design.

\subsection{PVMV Sap Extract Inoculation}

The inoculum was prepared by grinding $10 \mathrm{~g}$ of freshly harvested pepper leaves taken from the PVMV infected pepper plant in a sterilized mortal with a pestle in $20 \mathrm{ml}$ of $0.01 \mathrm{M}$ phosphate buffer, $\mathrm{pH} 7.3$; for sap extraction. The leaf shaft was removed from the sap extract containing the virus through the use of a cotton mesh.

Inoculation was carried out five days after transplant to allow for plant stability. Four young apical leaves of five weeks old pepper plant per plant was selected and dusted with 600-mesh carborundum as a source of abrasive to aid inoculation process and virus penetration. Sterilized cotton bud was dipped into the sap extract containing the virus and on each dusted leaf, a swab was done with the soaked cotton bud-containing virus from petiole of the leaf to the tip while supporting the leaf at the underside with fingertips. Five swabs of virus saturated cotton bud were made on each marked leaf renewing the inoculum in the bud frequently. The inoculated leaves were rinsed with sterilized distilled water to remove excess inoculum.

PVMV disease severities were then monitored on the potted pepper plants. The yield of the pepper fruit was also taken in each potted plant for a period of 12 weeks. Other agronomic data taken included; plant height, leaf number, internode's distance, and fruit number. The averages for two-year data were recorded and the results were analyzed statistically. Using analysis of variance procedure, the means were separated by using least significant difference (LSD) tests at five percent significance level.

\section{Results}

The electron microscopy of antiserum decorated isolated PVMV particles showed flexuous filamentous particles of $780 \mathrm{~nm}$ in length and $10 \mathrm{~nm}$ wide.

\subsection{Effect of Fertilizers Treatments on the Incidence and Severity of PVMV on the Varieties}

There was no significant difference in the two-year results collected, similar trend of results were observed. The application of poultry organic manure and the inorganic manure on the field cultivated pepper showed a high significant effect $(\mathrm{P}<0.01)$ on the incidence and severity of PVMV disease within the varieties and the treatments used (Table 1). There was also a significant difference in the occurrence of PVMV disease and its severity on the cultivated pepper in the interaction between the varieties and the fertilizers.

The potted pepper varieties had PVMV disease severity expressions that were not significantly different from each other in all the treatments (Table 1). But on the field cultivated pepper, PVMV disease incidence and severity varied significantly $(\mathrm{P}<0.05)$ in all the varieties, fertilizers applied and their interactions.

Interactions between varieties and fertilizers showed that the PVMV variety NHV1-G96 recorded the lowest PVMV disease incidence (25.67\%) and severity (26\%) when treated with 10 tons/ha poultry manure. At an application rate of 20 tons/ha poultry manure it was recorded 32.22\% PVMV disease incidence and 32\% severity. The inorganic manure treatment, recorded $49.53 \%$ PVMV disease incidence and $49 \%$ severity (Table 2). In the interaction between varieties and fertilizers PVMV susceptible variety NHV 1-E96 recorded the least PVMV disease incidence (33.31\%) and severity (33\%) which were not significantly different $(\mathrm{P}<0.05)$ from PVMV tolerant variety NHV1G96 (Table 2). Similar trends of observations were recorded in the potted pepper experiment. 


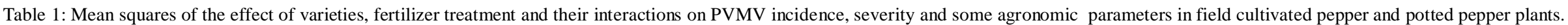

\begin{tabular}{|c|c|c|c|c|c|c|c|c|c|c|c|c|c|c|c|}
\hline \multirow[t]{2}{*}{ Source } & \multicolumn{3}{|c|}{ Plant height $(\mathrm{cm})$} & \multicolumn{2}{|l|}{ Leaf number } & \multicolumn{2}{|c|}{$\begin{array}{l}\text { Internode's } \\
\text { distance }(\mathrm{cm})\end{array}$} & \multicolumn{2}{|c|}{$\begin{array}{l}\text { Average number of fruit } \\
\text { /plant }\end{array}$} & \multicolumn{2}{|c|}{ Fruit yield (ton/ha) } & \multicolumn{2}{|c|}{$\begin{array}{l}\text { Viral disease } \\
\text { Incidence }(\%)\end{array}$} & \multicolumn{2}{|c|}{$\begin{array}{l}\text { Viral disease } \\
\text { Severity }(\%)\end{array}$} \\
\hline & Df & Pot & Field & Pot & Field & Pot & Field & Pot & Field & Pot & Field & Pot & Field & Pot & Field \\
\hline Fertilizer & 3 & $1630.2 * *$ & $7526.9 * *$ & $198421.5^{* * *}$ & $119058.2^{* * *}$ & $9.2^{* * *}$ & $5.1^{* * *}$ & $1142.7 * *$ & $10293.9 * *$ & $132833.4^{* * *}$ & $10.4^{* *}$ & & $7476.4 * *$ & $7.7 \mathrm{NS}$ & $0.7 * *$ \\
\hline $\begin{array}{l}\text { Variety } \\
\text { Fertilizer }\end{array}$ & 2 & $13189.3 * *$ & $24854.9 * *$ & $1193871.0 * *$ & $1094835.4^{* *}$ & $95.5^{* *}$ & $48.1^{* *}$ & $443.3^{* *}$ & $3932.4 * *$ & $122796.1 * *$ & $0.9^{*}$ & & $1157.2 * *$ & $5.3 \mathrm{NS}$ & $0.11 * *$ \\
\hline $\mathrm{x}$ Variety & 6 & $410.2 * *$ & $5221.2 *$ & $60654.04 * *$ & $41811.5^{* *}$ & $1.5^{*}$ & $2.2 * *$ & $185.5^{*}$ & $717.5^{* *}$ & $13094.5 * *$ & $0.2 \mathrm{NS}$ & & $296.2 *$ & $3.6 \mathrm{NS}$ & $0.02 *$ \\
\hline
\end{tabular}

** Significant at $P<0.01 \quad *$ Significant at $P<0.05 \quad N S=$ Not Significant

Table 2: The effects of varieties, fertilizer treatments and their interactions on PVMV incidence, severity and some agronomic parameters in field planted and potted pepper plants.

\begin{tabular}{|c|c|c|c|c|c|c|c|c|c|c|c|c|c|c|c|}
\hline \multirow{2}{*}{\multicolumn{2}{|c|}{$\begin{array}{l}\text { Treatment } \\
\text { Variety }\end{array}$}} & & \multirow{2}{*}{$\begin{array}{l}\begin{array}{l}\text { Disease } \\
\text { Incidence (\%) }\end{array} \\
\text { Field }\end{array}$} & \multicolumn{2}{|c|}{$\begin{array}{l}\text { Disease } \\
\text { Severity (\%) }\end{array}$} & \multicolumn{2}{|c|}{ Plant height (cm) } & \multicolumn{2}{|c|}{ Leaf number } & \multicolumn{2}{|c|}{$\begin{array}{l}\text { Internode's distance } \\
(\mathrm{cm})\end{array}$} & \multicolumn{2}{|c|}{$\begin{array}{l}\text { Average number of } \\
\text { fruit /plant }\end{array}$} & \multicolumn{2}{|c|}{$\begin{array}{l}\text { Fruit yield tons/ } \\
\text { hectare }\end{array}$} \\
\hline & & & & Pot & Field & Pot & Field & Pot & Field & Pot & Field & Pot & Field & Pot & Field \\
\hline & (1) & $40.9 \mathrm{a}$ & $38 \mathrm{a}$ & $40 \mathrm{a}$ & $24.0 \mathrm{c}$ & $26.5 b$ & $35.6 \mathrm{~b}$ & $50.52 \mathrm{~b}$ & $2.15 \mathrm{c}$ & $2.0 \mathrm{c}$ & $5.16 \mathrm{~b}$ & $13.1 \mathrm{c}$ & $0.12 \mathrm{~b}$ & $2.6 \mathrm{~b}$ \\
\hline \multicolumn{2}{|c|}{ NHV1-G96 } & (2) & $36.0 \mathrm{~b}$ & $38 \mathrm{a}$ & $36 \mathrm{~b}$ & $41.88 \mathrm{a}$ & $52.3 \mathrm{a}$ & $192.9 \mathrm{a}$ & $199.9 \mathrm{a}$ & $2.73 b$ & $2.6 \mathrm{~b}$ & $8.41 \mathrm{a}$ & $19.8 \mathrm{~b}$ & $0.38 \mathrm{a}$ & $3.2 \mathrm{a}$ \\
\hline \multicolumn{2}{|c|}{ NHV1-E96 } & (3) & $41.0 \mathrm{a}$ & $71 \mathrm{a}$ & $40 \mathrm{a}$ & $38.94 b$ & $43.7 \mathrm{a}$ & $193.7 \mathrm{a}$ & $203.1 \mathrm{a}$ & $3.76 \mathrm{a}$ & $3.2 \mathrm{a}$ & $7.93 \mathrm{a}$ & $23.4 \mathrm{a}$ & $0.35 \mathrm{a}$ & $2.45 \mathrm{~b}$ \\
\hline \multicolumn{3}{|c|}{$\operatorname{LSD}_{(0.05)}$} & 2.12 & 4.5 & 0.2 & 1.48 & 9.15 & 15.23 & 17.57 & 0.208 & 0.12 & 1.57 & 2.51 & 7.5 & 0.079 \\
\hline \multicolumn{3}{|c|}{ S.E \pm} & 0.96 & $\begin{array}{l}0.9 \\
7\end{array}$ & 0.09 & 0.57 & 2.25 & 4.2 & 6.12 & 0.067 & 0.047 & 0.60 & 1.12 & 3.52 & 0.035 \\
\hline \multicolumn{16}{|c|}{ Fertilizer (organic manure / inorganic fertilizer) } \\
\hline \multicolumn{3}{|c|}{0 tons/ ha } & $50.9 \mathrm{a}$ & $89 a$ & $51 \mathrm{a}$ & $30.33 d$ & $31.1 \mathrm{c}$ & $77.5 b$ & $104.9 \mathrm{c}$ & $2.66 \mathrm{~b}$ & $2.32 \mathrm{c}$ & $3.7 \mathrm{c}$ & $4.4 \mathrm{c}$ & $0.03 \mathrm{c}$ & $0.45 \mathrm{c}$ \\
\hline \multicolumn{3}{|c|}{10 tons/ ha Organic (2) } & $32.2 \mathrm{~d}$ & $33 b$ & $32 \mathrm{~d}$ & $39.41 \mathrm{a}$ & $51.2 \mathrm{a}$ & $156.95 \mathrm{a}$ & $183.3 \mathrm{a}$ & $3.29 \mathrm{a}$ & $2.82 \mathrm{a}$ & $11.1 \mathrm{a}$ & $23.9 \mathrm{a}$ & $0.42 \mathrm{a}$ & $3.7 \mathrm{a}$ \\
\hline \multicolumn{3}{|c|}{20 tons/ ha Organic (3) } & $34.8 \mathrm{c}$ & $35 \mathrm{~b}$ & $35 \mathrm{c}$ & $36.44 \mathrm{~b}$ & $38.8 \mathrm{bc}$ & $155.9 \mathrm{a}$ & $162.5 \mathrm{~b}$ & $2.86 \mathrm{~b}$ & $2.74 a b$ & $8.41 \mathrm{~b}$ & $25.5 \mathrm{a}$ & $0.39 \mathrm{a}$ & $3.75 \mathrm{a}$ \\
\hline \multicolumn{3}{|c|}{$260 \mathrm{~kg} / \mathrm{ha}$ Inorganic (4) } & $39.5 b$ & $39 a$ & $39 b$ & $33.44 \mathrm{c}$ & $42.5 \mathrm{ab}$ & $172.6 \mathrm{a}$ & $154.0 \mathrm{~b}$ & $2.7 \mathrm{~b}$ & $2.62 b$ & $5.47 \mathrm{c}$ & $21.5 b$ & $0.30 \mathrm{~b}$ & $3.05 b$ \\
\hline \multicolumn{3}{|c|}{$\operatorname{LSD}_{(0.05)}$} & 2.5 & 5.3 & 0.2 & 1.74 & 10.78 & 17.9 & 20.69 & 0.245 & 0.15 & 0.53 & 2.960 & 1.48 & 0.09 \\
\hline \multicolumn{3}{|c|}{ S.E \pm} & 0.05 & 0.9 & 0.08 & 0.97 & 3.13 & 9.6 & 12.84 & 0.097 & 0.27 & 0.64 & 1.09 & 3.58 & 0.03 \\
\hline \multicolumn{16}{|c|}{ Variety x Fertilizer (organic manure / inorganic fertilizer) } \\
\hline 1 & $\mathrm{x}$ & 1 & $53.05 \mathrm{a}$ & 50 & $53 a$ & $21.98 \mathrm{~g}$ & $26.2 \mathrm{de}$ & $35.25 \mathrm{e}$ & $48.7 f$ & $1.86 \mathrm{a}$ & $1.67 \mathrm{~g}$ & $2.67 \mathrm{~d}$ & $3.66 \mathrm{~d}$ & $0.02 \mathrm{~d}$ & $0.13 \mathrm{~d}$ \\
\hline 1 & $\mathrm{x}$ & 2 & $37.55 \mathrm{~cd}$ & 33 & $37 \mathrm{~cd}$ & $27.25 \mathrm{f}$ & $29.9 \mathrm{cde}$ & $34.64 \mathrm{e}$ & $61.9 \mathrm{f}$ & $2.27 \mathrm{a}$ & $2.3 \mathrm{de}$ & $10.22 \mathrm{ab}$ & $17.30 \mathrm{c}$ & $0.17 \mathrm{~d}$ & $3.3 \mathrm{a}$ \\
\hline 1 & $\mathrm{x}$ & 3 & $34.86 \mathrm{cde}$ & 31 & $35 \mathrm{cde}$ & $23.49 \mathrm{~g}$ & $23.6 \mathrm{e}$ & $39.17 \mathrm{e}$ & $45.8 \mathrm{f}$ & $2.28 \mathrm{a}$ & $2.2 \mathrm{ef}$ & $6.05 \mathrm{c}$ & $14.61 \mathrm{c}$ & $0.15 \mathrm{~d}$ & $3.6 \mathrm{a}$ \\
\hline 1 & $\mathrm{x}$ & 4 & $38.33 \mathrm{e}$ & 36 & $38 \mathrm{e}$ & $23.38 \mathrm{~b}$ & $26.4 \mathrm{de}$ & $33.28 \mathrm{e}$ & $45.7 f$ & $2.19 \mathrm{a}$ & 2.0ef & $1.66 \mathrm{~d}$ & $16.94 \mathrm{c}$ & $0.12 \mathrm{~d}$ & $3.3 \mathrm{a}$ \\
\hline 2 & $\mathrm{x}$ & 1 & $49.53 \mathrm{f}$ & 50 & $49 \mathrm{f}$ & $32.40 \mathrm{fe}$ & 26.8de & $119.53 \mathrm{c}$ & $162.0 \mathrm{~d}$ & $2.59 \mathrm{a}$ & $2.5 \mathrm{~d}$ & $6.41 \mathrm{c}$ & $6.47 \mathrm{~d}$ & $0.05 \mathrm{e}$ & $1.05 \mathrm{c}$ \\
\hline 2 & $\mathrm{x}$ & 2 & $25.67 \mathrm{a}$ & 28 & $26 a$ & $49.94 a$ & $78.8 \mathrm{a}$ & $223.66 b$ & $231.3 \mathrm{abc}$ & $3.25 \mathrm{a}$ & $3.1 \mathrm{~b}$ & $10.25 \mathrm{ab}$ & $24.91 \mathrm{~b}$ & $0.6 \mathrm{a}$ & $3.95 \mathrm{a}$ \\
\hline 2 & $\mathrm{x}$ & 3 & $32.22 \mathrm{f}$ & 36 & $32 \mathrm{f}$ & $45.87 \mathrm{~b}$ & $45.0 \mathrm{bcd}$ & $203.30 \mathrm{~b}$ & $199.5 \mathrm{c}$ & $2.54 \mathrm{a}$ & $2.5 \mathrm{~d}$ & $11.16 \mathrm{ab}$ & $28.25 \mathrm{~b}$ & $0.53 \mathrm{ab}$ & $4.2 \mathrm{a}$ \\
\hline 2 & $\mathrm{x}$ & 4 & $36.89 \mathrm{e}$ & 36 & $37 \mathrm{e}$ & $39.29 \mathrm{~cd}$ & $58.6 \mathrm{~b}$ & $225.02 b$ & $206.8 b c$ & $2.55 \mathrm{a}$ & $2 \mathrm{f}$ & $5.80 \mathrm{c}$ & $19.53 \mathrm{c}$ & $0.37 \mathrm{c}$ & $3.6 \mathrm{a}$ \\
\hline 3 & $\mathrm{x}$ & 1 & $50.36 \mathrm{ed}$ & 66 & $50 \mathrm{ed}$ & $36.63 d$ & 40.2 bcde & $77.61 d$ & $104.1 \mathrm{de}$ & $3.54 \mathrm{a}$ & $2.8 \mathrm{c}$ & $2.00 \mathrm{~d}$ & $2.92 \mathrm{~d}$ & $0.03 \mathrm{e}$ & $0.2 \mathrm{~d}$ \\
\hline 3 & $\mathrm{x}$ & 2 & $33.31 \mathrm{a}$ & 36 & $33 a$ & $41.05 \mathrm{c}$ & $44.7 \mathrm{bcd}$ & $212.55 b$ & $256.8 \mathrm{a}$ & $4.38 \mathrm{a}$ & $3.1 \mathrm{~b}$ & $12.70 \mathrm{a}$ & $29.39 \mathrm{ab}$ & $0.53 \mathrm{ab}$ & $3.8 \mathrm{a}$ \\
\hline 3 & $\mathrm{x}$ & 3 & $37.25 \mathrm{~cd}$ & 36 & $37 \mathrm{~cd}$ & $39.96 \mathrm{c}$ & $47.7 \mathrm{bc}$ & $225.08 b$ & $242.1 \mathrm{ab}$ & $0.14 \mathrm{a}$ & $3.5 \mathrm{a}$ & $8.00 \mathrm{bc}$ & $33.53 \mathrm{a}$ & $0.49 \mathrm{~b}$ & $3.45 \mathrm{a}$ \\
\hline 3 & $\mathrm{x}$ & 4 & $43.17 \mathrm{~b}$ & 45 & $43 b$ & $38.10 \mathrm{~cd}$ & 42.5 bcde & $259.55 \mathrm{a}$ & $209.6 \mathrm{bc}$ & $0.12 \mathrm{a}$ & $3.4 \mathrm{a}$ & $8.94 b c$ & $27.92 b$ & $0.31 \mathrm{c}$ & $2.2 \mathrm{~b}$ \\
\hline $\operatorname{LSD}_{(}$ & & & 4.135 & N.S & 0.41 & 2.88 & 17.84 & 29.69 & 34.24 & N.S & 0.2431 & 3.071 & 4.899 & 14.71 & 0.1554 \\
\hline S.E \pm & & & 1.488 & N.S & 1.48 & 1.037 & 6.416 & 10.68 & 12.32 & N.S & 0.087 & 1.105 & 1.762 & 5.293 & 0.055 \\
\hline
\end{tabular}

Means with the same letter are not significantly different from each other at $5 \%$ level of probability. 
Also there was significant difference in PVMV disease incidence and severity between the two susceptible varieties (NHV1-D96 and NHV1-E96) in the fertilizers applied in the field cultivated and potted pepper (Table 2). The application of 10 tons/ha poultry manure recorded the least PVMV disease incidence and severity compared with other fertilizer treatments applied both on the field cultivated pepper and potted pepper.

\subsection{Effect of Fertilizers Treatments on Pepper Yield and Agronomic Parameters}

The fertilizers applied and the varieties used showed a high significant effect $(\mathrm{P}<0.01)$ on the plant height, leaf number, internode's distance, number of fruit per plant and fruit yield in the field cultivated and potted pepper plants (Table 1). The effect of the interactions between the fertilizers and the varieties were also significant on the plant height, leaf number, internode's distance, number of fruit per plant and fruit yield.

There was a high significant variation in the mean plant height, leaf number, internode's distance, number of fruit per plant and fruit yield within the varieties, fertilizers and interaction between the varieties and the fertilizer treatments (Table 2). Variety NHV1-G96 varied significantly in all the fertilizer treatments and the varieties used. It had the highest mean height of $41.88 \mathrm{~cm}$ in potted pepper plants and $52.3 \mathrm{~cm}$ in field cultivated pepper plants while variety NHV1-D96 had the lowest mean height of $24.0 \mathrm{~cm}$ in potted pepper plant and $26.5 \mathrm{~cm}$ in field cultivated pepper plant. Varieties NHV1-G96 and NHV1-E96 recorded the highest leaf number both in the field cultivated and potted pepper. Variety NHV1-E 96 had longer internodes distance both in field cultivated and potted pepper plants, while variety NHV1-G96 had the highest mean yield compared with other varieties both in field cultivated and potted pepper plants.

Application of 10 tons per hectare of cured poultry litter as a source of organic manure to field cultivated pepper recorded the highest mean plant height (51.2 $\mathrm{cm})$, leaf number $(183.3)$, internode's distance $(2.82 \mathrm{~cm})$ and yield (3.7 tons/ha), while application of 0 tons per hectare recorded the lowest plant height $(31.1 \mathrm{~cm})$, leaf number (104.9), internodes distance $(2.32 \mathrm{~cm})$ and yield (0.45tons/ha) (Table 2). These trends of responses were also observed in the potted pepper plants.

The effect of the interactions between varieties and fertilizer treatments showed that variety NHV1-G96 at an application rate of 10 tons per hectare of cured poultry litter as source of organic manure recorded the highest plant height and fruit yield both in the field cultivated and potted pepper plants compared with other variety / fertilizer interactions (Table 2).

There was a significant interaction between the yield and the disease incidence and severity among all the varieties, because as disease incidence and severity increase it resulted in significant $(\mathrm{p}<0.05)$ reduction in the fruit yield (Figure 1)

\subsection{Effects of Application of Poultry Organic Manure on Soil Nutrients}

The soil particle size analysis before the application of poultry organic manure was made up of $91.30 \%$ sand, $1.8 \%$ clay, $6.9 \%$ silt. Using the guide for USDA soil textural classification (Robert Nuss et. al. 2001, Beth Jarvis, 2005) the soil was classified as sandy soil. The laboratory analysis of the soil nutrient before the application of poultry organic manure (Table 3) indicated an increase in the soil nutrient composition of the cultivated plot after eight weeks of pepper transplant, ten weeks after application of organic manure and five weeks after application of inorganic fertilizer especially in plots were poultry organic manure was applied while plots with inorganic fertilizer showed much increase in nitrogen, potassium and phosphorus levels (Table 4).

\section{Discussion}

The application of poultry organic manure and inorganic fertilizers did not prevent the occurrence of PVMV incidence and severity on the three cultivated varieties of pepper, but the PVMV characteristic symptoms and severity were expressed at varied degree, which were similar to earlier described symptoms (Green and Kim, 1991; Fajinmi et al., 1998; Robert et al., 2001). This suggest for the ability of PVMV to successfully infect pepper and its endemic nature on cultivated pepper.

Five agronomic parameters have been used in this study to determine the contributive effect of the poultry organic manure application on cultivated pepper plant infected with PVMV disease. The contributive effect was identified when values associated with the agronomic parameters of PVMV infected pepper plant that poultry organic manure has been applied, is greater than the values of those PVMV infected pepper plant that poultry organic manure was not applied. How and the manner this contributive effect has been made in the physiological structure of the PVMV infected pepper plant could not be determined in this study. 
Table 3: Soil nutrient composition per kilogram of sample before pepper seedling transplant

\begin{tabular}{|c|c|c|c|c|c|c|c|c|c|c|c|c|c|}
\hline & $\mathrm{pH}$ & $\begin{array}{l}\% \text { Organic } \\
\text { carbon }\end{array}$ & $\begin{array}{l}\% \text { Organic } \\
\text { matter }\end{array}$ & $\begin{array}{l}\text { Potassium } \\
\left(\mathrm{K}_{2}\right) \\
\mathrm{kg}\end{array}$ & $\begin{array}{l}\text { Sodium } \\
\left(\mathrm{Na}^{+}\right) \\
\mathrm{kg}\end{array}$ & $\begin{array}{l}\text { Calcium } \\
\left(\mathrm{Ca}^{2+}\right) \\
\mathrm{kg}\end{array}$ & $\begin{array}{l}\text { Magnesium } \\
\left(\mathrm{Mg}^{2+}\right) \\
\mathrm{kg}\end{array}$ & $\begin{array}{l}\text { \% Total } \\
\text { Nitrogen } \\
\text { kg }\end{array}$ & $\begin{array}{l}\text { Iron } \\
\mathrm{Fe}^{++} \\
\mathrm{kg}\end{array}$ & $\begin{array}{l}\text { Phosphorus } \\
\text { (P) } \\
\mathrm{kg}\end{array}$ & $\begin{array}{l}\text { Sulphur } \\
\text { (S) } \\
\mathrm{kg}\end{array}$ & $\begin{array}{l}\text { Zinc } \\
(\mathrm{Zn}) \\
\mathrm{kg}\end{array}$ & $\begin{array}{l}\text { Excess } \\
\text { Acidity } \\
\text { (ml) }\end{array}$ \\
\hline Poultry manure & 6.8 & 23.74 & 41.05 & 0.01626 & 0.0104 & 0.016 & 0.0027 & 0.018 & 0.012 & 0.025 & 0.00336 & 0.0002 & \\
\hline Soil & 5.53 & 0.3 & 0.52 & 0.0005 & 0.0008 & 0.0054 & 0.0084 & 0.00042 & 0.026 & 0.0013 & 0.00127 & 0.00032 & $0.6 \mathrm{ml}$ \\
\hline
\end{tabular}

Table 4: Soil nutrient composition per kilogram of soil sample after 8 weeks of pepper seedling transplant

\begin{tabular}{|c|c|c|c|c|c|c|c|c|c|c|c|c|c|}
\hline Plot & $\mathrm{pH}$ & $\begin{array}{l}\% \text { Organic } \\
\text { carbon }\end{array}$ & $\begin{array}{l}\% \text { Organic } \\
\text { matter }\end{array}$ & $\begin{array}{l}\text { Potassium } \\
\left(\mathrm{K}_{2}\right) \\
\mathrm{kg}\end{array}$ & $\begin{array}{l}\text { Sodium } \\
\left(\mathrm{Na}^{+}\right)\end{array}$ & $\begin{array}{l}\text { Calcium } \\
\left(\mathrm{Ca}^{2+}\right) \\
\mathrm{kg}\end{array}$ & $\begin{array}{l}\text { Magnesium } \\
\left(\mathrm{Mg}^{2+}\right) \\
\mathrm{kg}\end{array}$ & $\begin{array}{l}\text { \% Total } \\
\text { Nitrogen } \\
\mathrm{kg}\end{array}$ & $\begin{array}{l}\text { Iron } \\
\mathrm{Fe}^{++} \\
\mathrm{kg}\end{array}$ & $\begin{array}{l}\text { Phosphorus } \\
\text { (P) } \\
\mathrm{kg}\end{array}$ & $\begin{array}{l}\text { Sulphur } \\
(\mathrm{S}) \\
\mathrm{kg}\end{array}$ & $\begin{array}{l}\text { Zinc } \\
(\mathrm{Zn}) \\
\mathrm{kg}\end{array}$ & $\begin{array}{l}\text { Excess } \\
\text { Acidity } \\
\text { (Ml) }\end{array}$ \\
\hline Inorganic plot & & 0.4 & 0.58 & 0.0018 & 0.0022 & 0.0068 & 0.0092 & 0.00097 & 0.028 & 0.0056 & 0.0018 & 0.00028 & \\
\hline \multirow[t]{2}{*}{ Poultry manure plot } & A) 6.72 & 2.662 & 5.862 & 0.0214 & 0.026 & 0.025 & 0.0182 & \multirow{2}{*}{$\begin{array}{l}0.029 \\
0.032\end{array}$} & 0.024 & 0.054 & 0.0048 & 0.00026 & \\
\hline & В) 6.04 & 3.82 & 6.224 & 0.026 & 0.028 & 0.029 & 0.0189 & & 0.025 & 0.058 & 0.0049 & 0.00029 & \\
\hline Zero fertilizer plot & 5.54 & 0.28 & 0.55 & 0.00052 & 0.00078 & 0.0055 & 0.0080 & 0.00038 & 0.025 & 0.0015 & 0.0010 & $0.0003 k$ & $0.68 \mathrm{ml}$ \\
\hline
\end{tabular}

$A=10$ tons $/$ ha of poultry manure plot $\quad B=20$ tons/ha of poultry manure plot 


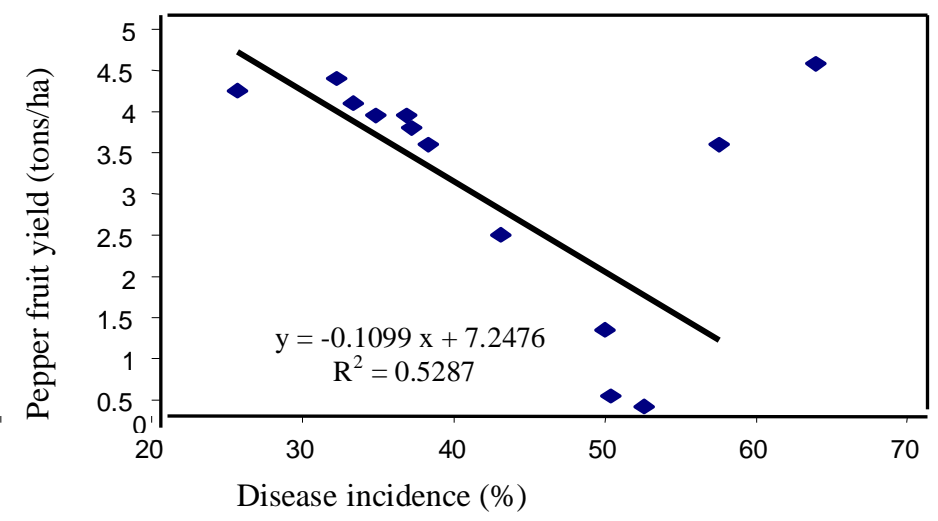

(A) Linear curve estimation showing reduction in the fruit yield of field cultivated pepper as disease incidence increases

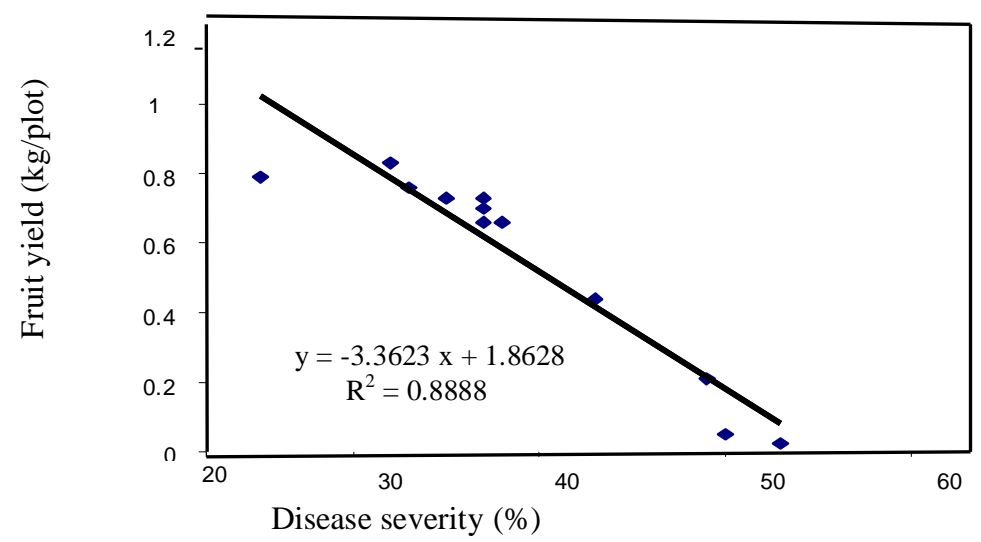

(B) Linear curve estimation showing reduction in potted pepper fruit yield as disease severity increases

Figure 1. The relation of pepper veinal mottle virus (PVMV) incidence (A) and severity (B) with pepper fruit yield

However, as noted by Robert et al., (2001) and Beth (2005), organic nutrient originates from living organism and are broken down in the soil by bacteria into water soluble forms to amend and condition the soil. It contains the required nutrients elements nitrogen $(\mathrm{N})$, phosphorus $(\mathrm{P})$, potassium $(\mathrm{K})$, magnesium $(\mathrm{Mg})$, calcium $(\mathrm{Ca})$, manganese $(\mathrm{Mn})$, Copper $(\mathrm{Cu})$, zinc $(\mathrm{Zn})$, iron $(\mathrm{Fe})$ and boron $(\mathrm{Br})$ ) which are gradually released in small amounts for plant use through the process of decay for a longer period of time, cation exchange capacity are increased, so that soils can hold and release more nutrients for good healthy growth of the plant.

The change and increase in the nutrient composition of the soil in plots that poultry organic manure had been applied, as suggested by Beth (2005), was due to the biodegrading activities of the soil microorganism on the organic matter leading to the slow release of nutrients into the soil compared with the commercial inorganic fertilizers where three major elements (NPK) are supplied and other elements supplied inform of impurities.

Pepper varieties that were fertilized with poultry organic manure, though infected with PVMV disease, had better reduction in PVMV disease incidence and severity and an increased fruit yield compared with the inorganic fertilizer and unfertilized infected varieties. This was due to the amounts of nutrients taken up, which determines the quantity of fruit and dry matter they produce, which in turn is influenced by a number of genetic and environmental variables as suggested by Hedge, (1986) and Green and Kim (1991).

The application of 10 tons/ha of poultry organic manure was observed by this study to be most effective in reducing PVMV disease incidence and severity and improving the yield potential of PVMV infected pepper variety. These compliment the reports by Green and Kim (1991) and Pottorff, (2004), that plants grown under good optimum conditions will have fewer disease 
problems. But the quantity of nutrients, which the farmer needs to apply, depends on the yield potential of that cultivar, the level of available plant nutrient already in the soil and growth condition. Thus, the significant reduction effect in the PVMV disease incidence and severity in all the cultivated pepper both on the field and potted pepper plant by the application of poultry organic manure as soil fertilizer treatment, might be due to the availability of constant slow release of required nutrient to the plant, which facilitated improvement in vigour of the pepper plant to develop a tolerance level to the PVMV infection.

Plants should be fertilized properly based on soil nutrient analyses using either organic or commercially prepared (inorganic) fertilizers. Control of most plant diseases can therefore be accomplished without pesticides, but Pottorff, (2004), reported it is important to realize that one must accept some disease caused loss.

\section{Acknowledgement}

We are very grateful to Dr. Stephan Winter, Head, DSMZ Plant Virus Division Braunschweig Germany for the virus electron microscopy and characterization.

\section{References}

Alegbejo, M.D. and Uvah I.I. 1987. Effect of intercropping pepper with tall companion crops on the incidence of pepper veinal mottle virus on pepper. Nigerian Journal of Entomology 7: $82-87$.

Beth, J. 2005. Yard and Garden Line News. University of Minnesota Extension Service, Volume 7, Number 6.

Cook, A.A. 1991. Pepper breeding for disease resistance. Capsicum Newsletter 10: 21 - 25.

Fajinmi, A.A, Oladiran, A.O. and Shoyinka, S.A. 1998. Relative susceptibility of pepper varities to pepper veinal mottle virus. International Journal of Tropical Plant Diseases 16: 41-48.

Gahukar, R.T. 1991. Current approaches to cassava pest management in sub tropical Africa. Agriculture Review 4: 97 - 136.

Gezerel, O., and Donmez, F. 1988. The effect of slow release fertilizers on the yield and fruit quality of vegetable crops growing in the Mediterranean area of Turkey. Acta Horticulturae 272: 63-69.

Green, S. K. 1991. Guide lines for diagnostic work in plant virology. Technical Bulletin $15,2^{\text {nd }}$ edition. Asian vegetable research and development center (AVRDC) publication. pp.35.

Green, S.K. and Kim, J.S. 1991. Characteristics and control of viruses infecting peppers. A literature review. Asian Vegetable Research and Development Centre. Technical Bulletin No. 18. pp. 7-60.
Hegde, D.M. 1986. Fruit development in sweet pepper (Capsicum annuum L.) in relation to soil moisture and nitrogen fertilization. Singapore Journal Primary Industries 14: 64-75.

Hussey, N.W. 1990. Agricultural production in the third world - a challenge for natural pest control. Experimental Agriculture 26: 171-183.

Kirkby, R. A. 1990. The ecology of traditional agro ecosystems in Africa. In: Altieri, M.A. and Hecht, S.B. (eds). Agro ecology and small farm Development. CRC Press, Boca Raton. p.p 173-180

Merritt, R., Nelson, T., Orum, V. and Ramon, J.G. 1999. Application of geographic information systems and geo-statistics in plant disease epidemiology and management. Plant Disease 83(4): 308-319

Olasantan, F.O. 1994. Fertilizer use in vegetable production in Nigeria. Outlook in Agriculture 23(3): 213-222

Pottorff, L.P., 2004. Non-chemical Disease Control. Colorado State University Cooperative Extension plant pathologist and horticulturist, Integrated Pest Management Program, Jefferson County. 6/92. Reviewed 12/03.

Robert, N., David, J., Sanford, L. and James, C. S. 2001. Soil Management in Home Gardens and Landscapes. Information and Communication Technologies. College of Agriculture Sciences, Agriculture Research and Cooperative Extension, the Pennsylvania State University. pp.1-8.

Steel, R. G. D. and Torrie, J. H. 1980. Principles of Statistics, $2^{\text {nd }}$ edition. McGraw-Hill Book Co., New York.

Zethner, O. 1991. Integrated pest and land management experiences and perspectives in the Gambia. Insect Science Application 12: 541-546. 